\title{
Hypothesis of Twin Deficits in Cote d'Ivoire: The Nonlinear Effect Analysis with a Smooth Transition Autoregression Model (STAR)
}

\author{
GREKOU Gahié Lopez ${ }^{1}$ \\ ${ }^{1}$ School of Economics, University Peleforo Gon of Korhogo, Republic of Cote d'Ivoire \\ Correspondence: GREKOU Gahié Lopez, School of Economics, University Peleforo Gon of Korhogo, Republic of Cote \\ d'Ivoire.
}

Received: November 19, 2020

Accepted: December 10, 2020

Available online: December 18, 2020

doi:10.11114/aef.v8i1.5018

URL: https://doi.org/10.11114/aef.v8i1.5108

\begin{abstract}
This paper tests the hypothesis of double deficit in Côte d'Ivoire in non-linear aid framework, using an autoregressive smooth transition model (STAR). The main results validate the hypothesis of double deficit in Côte d' Ivoire. The effect of current balance on budget balance is greater than budget balance on current balance. Moreover, the rapid effects of current account instability on fiscal balance reveal the lack of expectation by economic agents that leads to current account deterioration compared to the deterioration of budget balance. Thus, economic policies aimed at influencing the effect on current balance would be more effective than those aimed at the effect on budget balance. In other words, Ivorian economy adopts a Keynesian performance in the event of current account shocks and performance that tend to be more or less Ricardian in presence of fiscal policy shock.
\end{abstract}

Keywords: double deficits, star, Keynesian-ricardian performance, Cote d'Ivoire

JEL codes: E6, E7, C22, F32

\section{Introduction}

In United States, the crisis of the 1970s particularly stagflation revealed for the first time the joint existence of double deficit, budgetary and current account described as "twin" deficits. Four main theoretical approaches exist to analyze the double deficit. The two first approaches are within framework of traditional macroeconomic models explaining the mechanisms last the twin deficits: the Mundell-Fleming model (Mundell, 1963; Fleming, 1962) and the Keynesian theory of Absorption (Alexander, 1952). These theories explain the increasing in budget deficit leads to an increasing in current deficit. The third approach is called Current Account Targeting Hypothesis (CATH) (Summers, 1988) confirme the positive relationship between the two deficits. However, the Mundell-Fleming model is rather the current deficit that causes the budgetary deficit. According to another approach, as Ricardian equivalence (Barro, 1989), an increasing in budget deficit does not cause an increase in the external deficit.

At the level of sub-Saharan Africa, the existence of phenomenon of double deficits seems to be rare, since few studies have been carried out on this subject. However, in the WAEMU, a report by BCEAO (2013) questions us on the deterioration of current balance in relation to budget balance of certain member countries which have benefited from the HIPC initiative. In Côte d'Ivoire, the stock of debt 6373.9 billion reduced by the completion point of the HIPC programme to 2283.9 billion in 2012 has risen to 11607.77 billion in 2018 . This represents a debt growth rate of $31.12 \%$ against annual average GDP growth rate of 9.7\% in 2012-2018 periods. Therefore, the budget deficit which increases faster than the growth in production while prices of main raw materials which support the balance of trade are experiencing certain instability. This situation is similar to those of 1980s and 1990s, when Côte d'Ivoire was continually confronted with significant financial imbalances. A period marked by series of economic and financial crises in Africa countries with economies characterized by deep imbalances in public finances and balance of payments. In order to improve the macroeconomic situation, like other developing countries with difficulties payment, these countries sought financial assistance from World Bank and International Monetary Fund (IMF) through implementation of two different structural adjustment programmes ("SAPs") between 1981-1986. Despite the efforts made in the first and second SAPs, economic imbalances still persist in Côte d'Ivoire. In particular the consequences of budget deficits on macroeconomic variables. This budget deficit, when very large, crowds out private investment, a determinant of exports. As result, the budget deficit can be the cause of deterioration of current account. Government authorities and 
donors often believe quickly in success of stabilization efforts. However, most of these successes are due to turnaround in international economic situation. This delays the inking of fiscal and budgetary reforms that have been undertaken. As result, the decrease in raw materials does not anticipated in 1987-1993 period is combined with an erosion of tax incomes accompanied by persistent deficits.

Particularly this is a difficult macroeconomic context characterized by unsustainable levels of budget and current account deficits after 1984-1986 upturn. Indeed, the reduction in tax burden by 8 points is accompanied by an erosion of trade balance surplus and deterioration in current account deficit, which is up to $10 \%$ GDP. This double deficit which characterized Ivorian economy during this period was mainly financed by rescheduling of debt, arrears and accumulation of new external arrears. The persistence of these deficits is sign of failure of internal adjustment with the depreciation of the CFA franc finally imposing itself in 1993. After this reform, a phase of stabilization of public finances of Ivorian economy began between 1994-1998 with positive effects of deflation and rising in coffee and cocoa prices.

In view of decline of budget balance, the erosion of public finances on the whole and sometimes harmful effects on macroeconomic performance, this article analyses the asymmetrical adjustments linked to phenomenon of double deficits in Côte d'Ivoire. Specially, the hypothesis of double external and internal deficits is tested in non-linear framework in order to take into account structural changes affecting economic activity. Furthermore, it allows the dynamics in savings or investment performance of economic agents as result of the decisions of authorities in charge of budget to be assessed at the same time. This gives perspectives in terms of solutions to decision-makers who want to satisfy domestic demand (absorption) compromise the external balance and vice versa. Most of the economic literature agrees on causal link between these two deficits but opposes to the direction of causality between these domestic and external deficits. However, taking into account structural breaks in explanation of double deficit remains to be explored and may influence the direction of causality. Given the various structural changes that have occurred in the Ivorian economy as result of numerous shocks that have led to significant and sometimes uncovered expenditure, to what extent the deficit in the state budget weaken the current account balance?

We explain these relationships by adopting an econometric cointegration methodology that analyses the short and long term impact in this deficit relationship in the first case. In particular, our analysis of long-term relationship is carried out in non-linear model to account for regime changes. In second step, taking into account the fact that most of adjustments are not abrupt, we adopt a second method based on smooth transition autoregressive model (STAR) that highlights flexible regime changes. The second section of our work then focuses on the theoretical framework before presenting the econometric methodology of the STAR model and data sources in the third section. Sections 4 and 5 present respectively the interpretation of empirical results and the economic policy implications.

\section{Literature Review and Analytical Framework}

The theoretical framework for this analysis has been developing since the work of Keynes and Ricardo. Based on this framework, several researches analyze empirically the sense of causality between the two deficits. This is the consequence of the increased interest of economists and decision-makers in these two imbalances in the economy.

\subsection{Literature Review}

The two major frameworks for analyzing twin deficits are Keynesian and neoclassical approaches. While the Keynesian approach supports a causality ranging from the budget deficit to current account deficit, the other approach, known as Ricardian equivalence opposes the effects of budget deficit on current account deficit. According to empirical studies, two techniques can be used to identify the existence of deficits twins. Authors such as Miller and Russek (1989); Khalid and Guan (1999); Normandin, (1999); Piersanti (2000); Kouassi et al (2004); Marinheiro (2008); Holmes (2011) explain double deficits by limiting themselves to two variables. However, some authors reveal that the causality between the two deficits is significantly influenced by other macroeconomic variables. These include Darrat (1988) through the interest rate transmission mechanism and Abell (1990); Baharumshah (2006), and Kalou and Paleologou (2012) through the exchange rate channel. Rosensweig and Tallman (1993) show that an increase in the US fiscal déficit leads to an appreciation of US dollar, and hence of the current déficit. Authors such as Kim (2006), Afonso and Rault (2008), Rault and Afonso (2009) test the twin deficits by considering the role of exchange rates, while others (Daly and Siddiki, 2009; Grier and Ye, 2009) consider interest rates. Dibooglu (1997) uses Mundell-Fleming's model to conclude that the rise in the fiscal deficit and the rise in real interest rates are related to the rise in external balance deficit.

Mohammadi (2004) analyses the effect of fiscal policy on current account balance using panel data from 1975-1998 for 63 countries, including 20 industrialized countries and 43 developed countries. Firstly, he concludes, that there is a negative effect of the decline in public savings on current account. Secondly, a significant negative effect of increasing in financing of government expenditure through current account bonds compared to alternative financing through 
taxation. These results are different to the predictions of Ricardian theory but they are consistent with the prediction of conventional theory that budget deficit is primary cause of current account deficit.

Kaufmann et al. (2002) reject the assumption of double deficit on quarterly data from 1976 to 1998, using an error-correction model in the case of Australia. When Zubaidi et al, (2002) detect long-term relationship between budget deficits and current account deficits in ASEAN. They find that Keynesian approach is confirmed for Thailand since it is the budget deficit that causes the current account deficit. For Indonesia the causality is the opposite. Whereas Malaysia and Philippines, the causality goes in both directions. To reach to these results, vector autoregression models (VARs) are widely used. Recently they are models with structural breaks (Kim, 2006) and error correction models with structural breaks (Daly and Siddiki, 2009). Another generation of models is increasingly used to analyze non-linearity of certain variables that present certain instability, especially in the macroeconomic and financial field. This is the case of autoregressive smooth transition model (STAR). These models focus mainly on uni-variaty framework when threshold co integration models (Enders and Siklos, 2001) look at asymmetric effects in multivariate framework.

\subsection{Analytical Framework}

The accounting balance which remains an identity is relevant for economic policy analysis as it establishes the link between current account and debt. Thus, the difference between exports (X) and imports (M) of goods and services is referred to a current account balance (CA), so:

$$
C A=X-M
$$

When a country's level of imports exceeds its exports, it has a current account deficit; otherwise it is a current account surplus. So:

$$
Y=C+I+G+X-M
$$

With $Y$ is the production level, $C$ represents the consumption, $I$ the investment and public expenditure is depicted by $G$. The equation indicates that any change in current account balance can be associated with a change in output and employment. The current account balance then measures the size and direction of international loan. When a country imports more than it exports, it buys more abroad than it sells there and has to finance this deficit. This country can only import more than it exports if it can borrow the difference abroad. It will have to increase its net foreign debt by the amount of this deficit. On the other hand, a country with current account surplus earns more from its exports than it spends on its imports. It finances the current account deficit of its trading partners by lending them money.

The previous relationship allows us to show that current account balance is the difference between national income and domestic residents' expenditures (absorption) which implies that national savings play a decisive role in national accounts.

$$
C A=Y-(C+I+G)
$$

In accordance with the relationship (3) national savings (S) consisting of private $(\mathrm{Sp}$ ) and public (Sg) savings can be written:

$$
\begin{array}{r}
S_{p}=Y-T-C \\
S_{g}=T-G
\end{array}
$$

Where

$$
\begin{gathered}
S_{p}+S_{g}=S \\
\text { And } \\
(Y-T-C)+(T-G)=S \\
\text { As : } \\
S=Y-C-G
\end{gathered}
$$


To know the effects of these savings in an economy, we return to the equation

$$
\begin{gathered}
S p+S g=S \text { which is: } \\
S=I+C A \\
S_{p}=I+C A+S_{g} \text { which is : } \\
S_{p}=I+C A+(G-T)
\end{gathered}
$$

The equation links private $S p$ savings to domestic investment, the current account surplus and public savings $S g$.

The state budget deficit (- $S g$ or $-(G-T)$ ) tells us to what extent the government borrows to finance its expenditures.

Thus, a country's savings can take three forms: investment ( $I$ ), the acquisition of external assets reflected in the current account $\mathrm{CA}$ and the purchase of government-issued bonds - $(G-T)$

In short run, the equation can be specified as:

$$
C A=S p-I-(G-T)
$$

And shows to what extent the state budget deficit can weaken the current account or the inverse relationship. Under these conditions, the deficit in the State budget caused by the reduction in taxes and the increase in foreign purchases may prove to be a source of current account deficit. In return, the current account deficit may be related to domestic investment supported by public spending or debt.

\section{Econometric Methodology}

The main methodology adopted is based on STAR models derived from autoregressive threshold models (TAR). Non-linear autoregressive smooth transition models (STAR) have property of capturing state dependency characteristics and allowing trend of financial variables to change more flexibly than abruptly (discretely). After analyzing the direction of causality between the budget and trade balances, we use the STAR models to analyze the reaction of these balances in presence of possible structural break. Recent analyses of the relationship between current account and budget deficit suggest that "double deficit" relationship is subject to structural changes. We explain these relationships by adopting an econometric co integration methodology that analyses the interactions between deficits in presence of structural breaks on the one hand. We adopt a second method using smoothed transition variables (STARs) to highlight these threshold effects on the other hand. This method follows the discrete transition variable threshold model. The discrete threshold regression model describes a simple form of non-linear regression characterizing some of linear specifications and regime changes that occur when an observed variable crosses unknown thresholds. Before presenting the STAR models, let us first describe the threshold unit root tests that study stationary as function of regime.

\subsection{Threshold Unit Root Tests}

The time series of current balance $(b c)$ and budgetary balance $(s b)$ are tested for a unit root using the ADF-Dickey and Fuller (1979) test. The order of lags in regression according to AIC criteria. The use of unit root testing to differentiate trend and stationarity of series has become essential in applied research. For Perron (1989), structural changes and unit roots are closely related and conventional unit root searches are biased towards the null hypothesis of unit root when the data have stationary trends with a structural break. It is therefore essential to define variables that allow us to notice these breaks. Then the following variables are defined in terms of specific break date $t b$,

- A break variable in the constant

$$
D U_{t}\left(T_{b}\right)=1\left(t \geq T_{b}\right)
$$

This takes the value 0 for all dates before the break and 1 after.

A dummy variable that breaks over a period of time can be expressed as follow:

$$
D_{t}\left(T_{b}\right)=1\left(t=T_{b}\right)
$$


This takes the value 1 only on the break date and 0 elsewhere. In general framework, we specify different models for null and alternative hypothesis by placing zero restrictions on one or more trends and breaks $\beta, \theta, \gamma, \gamma, \omega$ parameters. Following Perron (1989), Perron and Vogelsang (1992a, 1992b), and Vogelsang and Perron (1998), we consider four different Dickey-Fuller regression specifications that correspond to the different assumptions for trend and break point we have.

Model 0: data without trend with break in the constant:

$$
Y_{t}=\mu+\theta D U_{t}\left(T_{b}\right)+\gamma D_{t}\left(T_{b}\right)+\omega D_{t}\left(T_{b}\right)+\alpha Y_{t-1}+\sum_{i=1}^{k} c \Delta Y_{t-i}+\mu_{t}
$$

Model 1: data with trend and break in the constant:

$$
Y_{t}=\mu+\beta t+\theta D U_{t}\left(T_{b}\right)+\omega D_{t}\left(T_{b}\right)+\alpha Y_{t-1}+\sum_{i=1}^{k} c \Delta Y_{t-i}+\mu_{t}
$$

Model 2: data with trend and with break in the constant and break in the trend:

$$
Y_{t}=\mu_{t}+\beta t+\theta D U_{t}\left(T_{b}\right)+\gamma D_{t}\left(T_{b}\right)+\omega D_{t}\left(T_{b}\right)+\alpha Y_{t-1}+\sum_{i=1}^{k} c_{i} \Delta Y_{t-1}+\mu_{t}
$$

Model 3: data with trend and break in the trend:

$$
Y_{t}=\mu_{t}+\beta t+\gamma D_{t}\left(T_{b}\right)+\alpha Y_{t-1}+\sum_{i=1}^{k} c_{i} \Delta Y_{t-1}+\mu_{t}
$$

The estimates of these models allow us to test the stationarity of budget balance $(s b)$ and current balance $(b c)$ variables by integrating the effects of structural breaks in the series.

\subsection{The STAR Model and the Basic Theoretical Framework}

We adopt the framework of the autoregressive smooth transition models developed by (Chan and Tong, 1986; Luukkonen, Saikkonen and Teräsvirta, 1988) to analyze the dynamics between the internal and external deficit. Threshold specifications are popular because they estimate, interpret and capable of producing interesting non-linearity and good dynamics. The basic representation of STAR model of univariate series can be specified as follows:

$$
\Delta Y_{t}=\phi^{\prime} x_{t}+\vartheta^{\prime} x_{t} G\left(s_{t}, \gamma, c\right)+\varepsilon_{t}
$$

Where $\Delta$ is the first difference operator, $y_{t}$ is the dependent variable ; $x_{t}\left(1, y_{t-1}, y_{t-2}, \ldots, y_{t-p}\right)$ is a vector that represents all the explanatory variables on the right, $\phi=\left(a, \phi_{1}, \phi_{2}, \ldots, \phi_{p-1}\right)^{\prime}$ and $v=\left(a, v_{1}, v_{2}, \ldots, v_{p-1}\right)$ are parameter vectors to be estimated $G\left(s_{t} ; \gamma, c\right)$ is a continuous transition function, which is between 0 and 1 , and $s_{t}$ is the transition variable. The parameter $\gamma$ represents the speed of the transition, while c reflects the break or threshold between two regimes. $\varepsilon_{t}$ is the error term such as $\varepsilon_{t} \square i d d\left(0, \alpha^{2}\right)$. This model is defined as two regime change models, in which the transition function $\mathrm{G}$ allows the dynamics of the model to change between regimes. A common specification of the generalized version of the transition functions is given by:

$$
G\left(s_{t} ; \gamma, c\right)=\left\{1+\exp \left[-\gamma / \sigma_{s t}^{k}\left(\Pi_{k}\left(s_{t}-c_{k}\right)^{k}\right]\right\}^{-1}\right.
$$

Where $\sigma_{s t}^{k}$ is the standard deviation of the transition variable. The two main versions adopted in the studies in the 
general transition functions (smoothed) to explain the regime change models of financial variables are logistic and exponential functions, corresponding respectively to the logistic STAR (LSTAR) and exponential STAR (ESTAR) logistic functions. A logistics function can be derived from the general transition functions by imposing $k=1$. From this point on, it is possible to treat asymmetry in autoregressive dynamics.

$$
G\left(s_{t} ; \gamma, c\right)=\left\{1+\exp \left[-\gamma / \sigma_{s t}\left(s_{t}-c\right)^{k}\right]\right\}^{-1}, \gamma>0
$$

In addition, an alternative exponential function can be represented as:

$$
G\left(s_{t} ; \gamma, c\right)=\left\{1+\exp \left[-\gamma / \sigma_{s t}^{2}\left(s_{t}-c\right)^{2}\right]\right\}^{-1}, \gamma>0
$$

If $\gamma$ is large, the logistic and exponential transition functions go from 0 to 1 more quickly and the opposite is true if $\gamma$ is small. As shown in the figure when $\gamma \rightarrow 0$, the logistic function $G($.$) approaches the value of constant and the LSTAR$ model is reduced to the linear AR model. Otherwise, this model converges on the autoregressive threshold model (TAR) when $\gamma \rightarrow \infty$. The ESTAR model is reduced to linear AR model as well as when $\gamma \rightarrow 0$ and $\gamma \rightarrow \infty$.

\subsection{Non-linearity Test and Estimation}

Teräsvirta, (1989) provided details on the procedures for STAR modelling process. The first step is the identification of the autoregressive estimation delay (AR) criterion; the Bayesian Schwartz criterion (SBC) or the Akaike information criterion (AIC) are generally used to determine optimal delay. The second step is the linearity test. The linearity test is usually the first step adopted for non-linear models, so the non-linear framework including STAR models should only be used if the null hypothesis of non-linearity is rejected; otherwise a linear model would be appropriate to model the underlying data. Testing linearity against non-linearity of the STAR type involves testing the null hypothesis $H_{0}: \vartheta=0, \gamma$ and they are nuisance parameters and will take some values as they will not be identified under the null assumption. Alternatively, if the null hypothesis is $H_{0}: \gamma=0$, then neither $\vartheta$ nor $\mathrm{c}$ will be identified. To solve this problem, Lukkonen and al., (1988) propose an auxiliary regression sequence by replacing the transition function $G\left(s_{t} ; \gamma, c\right)$ with the Taylor series approximation. Thus, the use of low order power in the auxiliary regression of the logistic function can make the explosive process and time series model irrelevant, Lukkonen and al., (1988) suggest the inclusion of third order parameters. Thus when the transition function in LSTAR is replaced by the development of third-order Taylor series, the LSTAR model can be specified as:

$$
\Delta y_{t}=\vartheta_{0}^{\prime} x_{t}+\sum_{i=1}^{3} \vartheta_{i}^{\prime} s_{t}^{i}+e_{t}
$$

Where $\Delta$ is the first difference operator, which is $\Delta y_{t}=y_{t}-y_{t-1}, e_{t}$ is the error term that combines the original error term (the random deviation) $\varepsilon_{t}$, and the error from the Taylor development. $\vartheta_{i}=\left(\vartheta_{1}, \vartheta_{2}, \vartheta_{3}\right)^{\prime}$ are auxiliary regression parameter vectors. The null hypothesis of linearity under the auxiliary regressions of the non-linear STAR model, $H_{0}^{\prime}=\vartheta_{1}=\vartheta_{2}=\vartheta_{3}=0$ can be tested against non-linear STAR models using Lagrange multiplier (LM) test statistics with an asymptotic distribution of $\chi^{2}$. After checking the existence of non-linearity of the time series, the last step is to set 
the transition variables and select a sequence of transition functions $G\left(s_{t} ; \gamma, c\right)$ and determine the appropriate type of STAR model. The specification of the STAR model can be done on the basis of sequence of hypothesis tests in the context of the previous equation we have:

$$
\begin{gathered}
H_{0,1}: \vartheta_{3}=0 \\
H_{0,2}: \vartheta_{2}=0 / \vartheta_{3}=0 \\
H_{0,3}: \vartheta_{1}=0 / \vartheta_{2}=\vartheta_{3}=0
\end{gathered}
$$

The linearity test against the STAR model is equivalent to the test of null hypothesis of $H_{0,1}$ and $H_{0,2}$, alternatively the test against the ESTAR model relates to the hypothesis. The rule for choosing between the LSTAR and ESTAR models is offered by Teräsvirta (2005). If $H_{0,1}$ is rejected, we choose the LSTAR model. But if $H_{0,1}$ is accepted and $H_{0,2}$ is rejected this translates the choice of the ESTAR model against LSTAR. Alternatively, if $H_{0,1}$ and $H_{0,2}$ are accepted but $H_{0,3}$ rejected this reflects the choice of an LSTAR model. Thus, the appropriate model is selected and the model can be estimated as non-linear model (see Table 9, and Table 10 in appendix).

\subsection{Data Sources and Stylized Facts}

Our data are extracted from the database of the BCEAO (Central Bank of West African States) covering the period from 1965 to 2017 (see Table 1).

Table 1. Variables definition

\begin{tabular}{l|l|l}
\hline Variables & Measure & Sources \\
\hline$b c$ & Current balance in percentage of Gdp & $\begin{array}{l}\text { Central Bank of West African States } \\
\text { (BCEAO) }\end{array}$ \\
\hline$s b$ & $\begin{array}{l}\text { Primary Budgetary balance excluding } \\
\text { grant in percentage of Gdp }\end{array}$ & $\begin{array}{l}\text { Central Bank of West African States } \\
\text { (BCEAO) }\end{array}$ \\
\hline
\end{tabular}

Source: Author

Changes in external and budgetary balances compared to their respective trends (Figure 1), through the Hodrick and Prescott filter, show the instability of these two balances. Furthermore the most important "peaks" or "troughs" can be found around the year 1990. This is an important breaking point coinciding with the structural changes in this period.

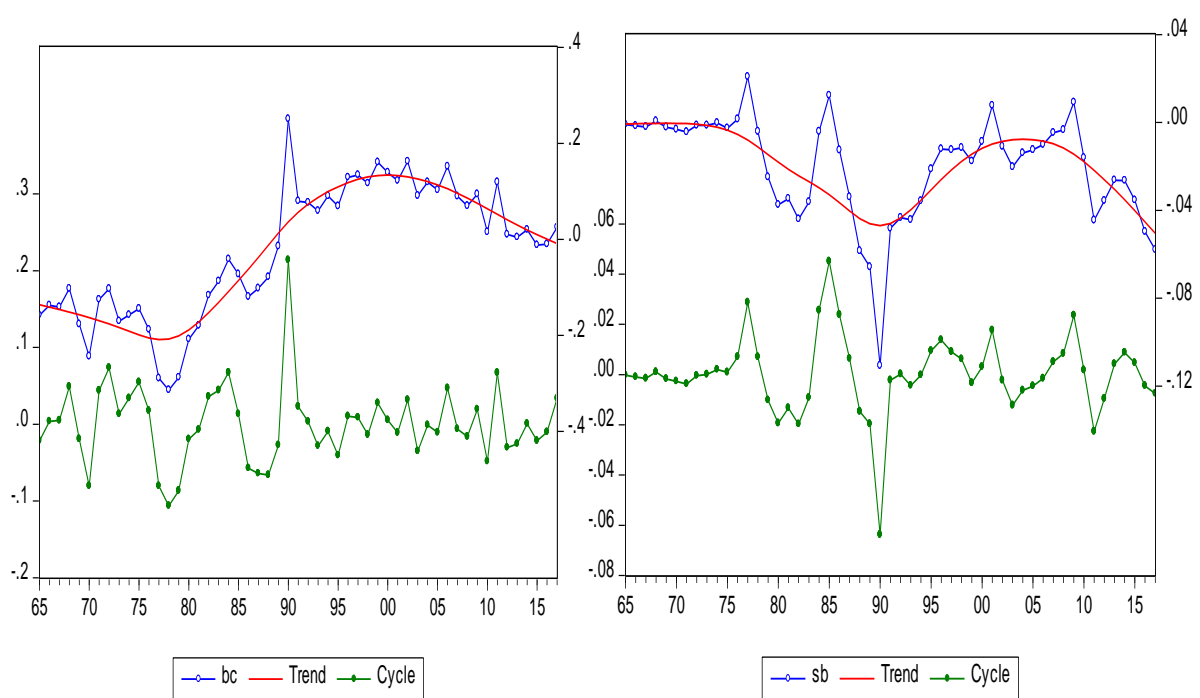

Figure 1. Cycle trend decomposition by the Hodrick-Prescott (1997) filter of the current balance ( $b c$ ) and budgetary balance ( $s b$ ) variables 1965-2017 
Note: The filter of Hodrick and Prescott (1997) takes into account a smoothing constant $\lambda$ which represents the division of fluctuations between long-term trends and short-term fluctuations. They set this constant at 100 for annual series (see Boone, 1995). Source: the author based on BCEAO data

The joint evolution of the current and fiscal balance highlights a relatively more volatile current account balance than the fiscal balance (Figure 2). Moreover, this figure shows that these balances sometimes move together i.e follow the long term relationship (1975-1995 and 2005-2015).

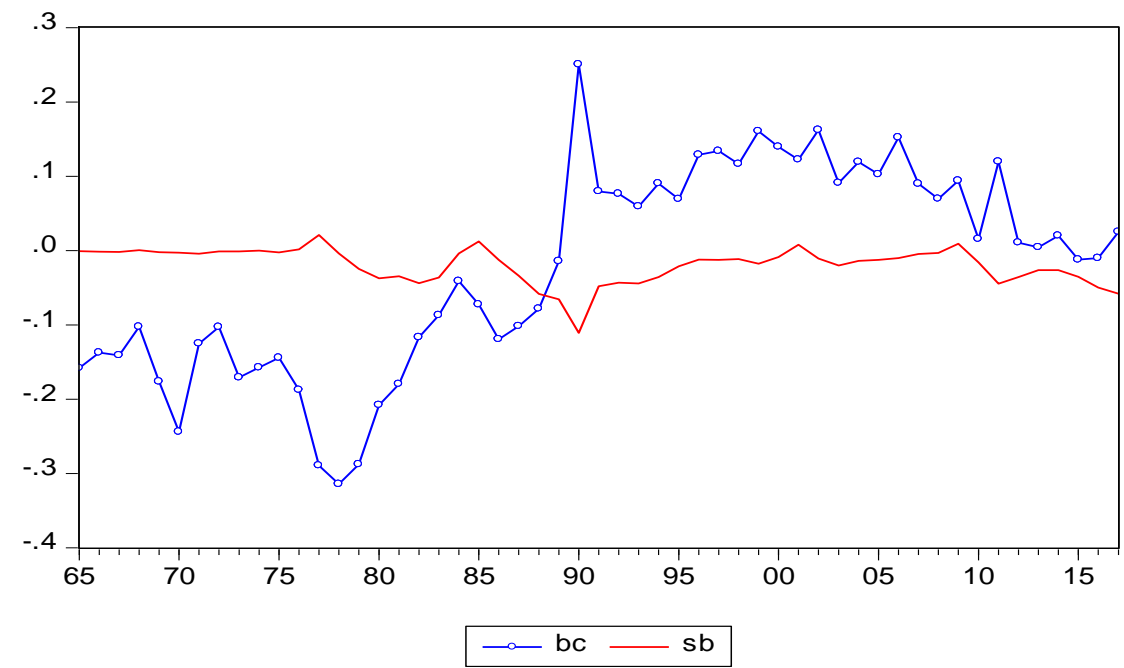

Figure 2. Joint evolution of the current account $(b c)$ and the budgetary balance $(s b)$ 1965-2017

Source: the authors based on BCEAO data.

\section{Empirical Results and Interpretations}

\subsection{The Break Tests and Unit Root Tests}

Firstly, Quandt-Andrews break tests (Table 2) are adopted because they have the property of detecting an unknown failure point in advance. The null hypothesis of no breakpoint is rejected at the $1 \%$ level (the F-statistic with p-value of 0,000). Wald and LR's F-statistics make it possible to detect a breaking point in 1990, years marked by major socio-economic reforms in Côte d'Ivoire, or among its main trading partners. Similarly, in WAEMU, where currency, credit and community reforms have undergone profound changes.

Table 2. Quandt-Andrews break tests

\begin{tabular}{lcc}
\hline \multicolumn{1}{c}{ Statistics } & F-statistic & P-value \\
\hline Maximum LR F-statistic (1990) & & 0,000 \\
Maximum Wald F-statistic (1990) & 80,248 & 0,000 \\
Exp LR F- statistic & 160,497 & 0,000 \\
Exp Wald F- statistic & 36,784 & 0,000 \\
With LR F- statistic & 160,497 & 0,000 \\
With Wald F- statistic & 30,177 & 0,000 \\
\hline Source: the author & 60,354 & \\
\hline
\end{tabular}

Source: the author based on BCEAO data

The results of these tests show that we are dealing with instability of the model's coefficients. This requires an adoption of unit root tests taking into account this breakpoint. Secondly, two types of stationarity tests are used. The first step is to test stationarity in a linear framework. Then, in a second step an analysis of stationary with structural breakdown is carried out in the light of a number of socio-economic events that have led the authorities to structural reforms. The linear unit root tests are grouped into two blocks. These are the common and individual unit root tests. The Levin, Lin and Chu statistics from the common unit root tests of the budget balance and current variables indicate that these two variables are stationary at the same level. Similarly, these results are confirmed for each series with respect to the 
individual unit root test statistics of Im, Pesaran and Shin and the statistics of ADF - Fisher and these results are depicted in Table 3 bellow.

Table 3. Unit root tests without structural break for the series $b c$ and $s b$

\begin{tabular}{llll}
\hline & T-statistics & p-value** & Number of observations \\
\hline $\begin{array}{l}\text { Common unit root test } \\
\text { Levin,Lin and Chu statistics }\end{array}$ & 11,850 & 0,000 & 102 \\
\hline Common unit root test individual unit root & & & 102 \\
Im, Pesaran and Shin W-stat & $-10,303$ & 0,000 & 102 \\
ADF - Fisher Chi-square & 71,883 & 0,000 & 102 \\
PP - Fisher Chi-square & 77,610 & 0,000 & \\
\hline
\end{tabular}

Note: ** The probabilities of the Fisher tests are calculated using an asymptotic distribution of $\mathrm{x} 2$. Source: the author from BCEAO data

On the contrary, unit root tests for a structural break in ADF shown in Table 4 bellow indicates that the variables are stationary in first difference. The year 1990 is detected as the date of rupture, a period marked by many socio-political tensions. Tensions resulting in structural reforms including the process of market liberalization, currency and credit policy reform and the transition from monetary union to economic and monetary union.

Table 4. Unit root test with 1 structural break

\begin{tabular}{|c|c|c|}
\hline & First Difference & First Difference \\
\hline & $b c$ & $s b$ \\
\hline TB & 1990 & 1990 \\
\hline$\mu$ & $0,006(0,010)$ & $-0,002(\quad 0.003)$ \\
\hline$\theta$ & $-0,014(0,014)$ & $0,004(0,004)$ \\
\hline$\gamma$ & $0,293 * * *(0,053)$ & $-0,047 * *(0,016)$ \\
\hline$\alpha$ & $-0,318^{* *}(0,111)$ & $-0,015(0,134)$ \\
\hline$R^{2}$ & 0,426 & 0,159 \\
\hline Critic & & \\
\hline $1 \%$ & $-4,949 * * *$ & \\
\hline $5 \%$ & $-4,443 * *$ & \\
\hline $10 \%$ & $-4,193 *$ & \\
\hline
\end{tabular}

Note: $* * *$ significant at $1 \%, * *$ significant at $5 \%, *$ significant at $10 \%$ and standard deviations in brackets.

Source: author table based on BCEAO's data

Reforms in the conduct of monetary and fiscal policy are expected to bring financial stability to WAEMU. Consequently, the linear and non-linear cointegration tests can help us to assess the situation in Côte d'Ivoire since its independence in 1960 and the period before and after these structural changes that occurred from 1990 onwards. To better illustrate the asymmetric effects of shocks on the fiscal and current account, it is essential to investigate the existence of long-term relationship and determine the direction of causality. The tests commonly used in co integration analysis are those of Juselius and Johansen (1989). They are justified insofar as they make it possible to carry out short and long-term analysis if necessary. As for Granger causality tests, they suggest a possible sense of causality for the variables used.

\subsection{Causality and Co Integration Tests}

The Granger (1986) causality test statistic exposed in Table 11 indicates that the null hypothesis of lack of causality from the current balance to the budgetary balance is not rejected. This translates into an F-statistics $(=3.684)$ for a p-value of $0.032<0.05$ over the period 1965 to 2017. On the other hand, over the period 1965 to 1990 , the same Granger causality test does not reject the null hypothesis of lack of causality from the budget balance to current account (see Table 11 in appendix). This result is illustrated by the F-statistics $(=8.229)$ for p-value of $0.002<0.05$. For the period 1991 to 2017, the null hypothesis of no causality in direction of the current balance towards the budget balance is rejected at the $5 \%$ level $(\mathrm{F}$-stat $=6.560)$ for $\mathrm{p}$-value of $0.006<0.05$. In so doing, the co integration tests adopted in our 
framework are two types. First, it is a long-term relationship analysis test without interruption and another long-term relationship analysis test with interruption in 1990. The following Table 5 shows the results of the seamless co integration tests. In accordance with this, the trace and maximum likelihood tests do not indicate any co integration relationship at $5 \%$ threshold between the budget balance $(s b)$ and the current balance $(b c)$. Thus, when the deterministic components of fiscal and current balances do not experience structural breaks, the results of Johansen's co integration tests do not reject the null hypothesis of no co integration. If no threshold effect is considered, these results indicate that the two balances do not evolve together in long term. In other words, none of these balances is dependent on the other in the long term.

Table 5. Johansen co integration tests between budget balance $(\mathrm{sb})$ and current balance $(\mathrm{bc})$ without structural break 1965-2017

\begin{tabular}{lccccc}
\hline $\begin{array}{l}\text { Nombre d'équation } \\
\text { cointégration }\end{array}$ & de & Nulle & Statistique & Valeur critique 5\% & Probabilité* \\
\hline $\begin{array}{l}\text { H1(r) Maximum } \\
\text { vraisemblance }\end{array}$ & de & $r=0$ & 11,658 & 0,263 \\
\cline { 2 - 5 } & & $r \leq 1$ & 3,567 & 17,147 & 0,058 \\
\hline H1(r) Trace & $r=0$ & 0,207 & 3,84 & 0,131 \\
& $r \leq 1$ & 0,068 & 18,397 & 0,058 \\
\hline
\end{tabular}

Note: the optimal lag of this test is chosen according to AIC and SC criteria, * indicates a probability at the $5 \%$ threshold.

Source: Author based on BCEAO data.

The co integration test of Johansen (1988), Johansen and Juselius (1990) between budget balance $(s b)$ and current balance $(b c)$ without structural break does not reject the null hypothesis of no co integration at $5 \%$ threshold see Table 6 . We therefore envisage an analysis integrating breaks in the constant and through a dummy variable. The break variable in the constant takes the value 0 for all dates before and after the break, so $D U_{t}\left(T_{b}\right)=1\left(t>T_{b}\right)$. While the break dummy variable over the period considered takes the value 1 only on the break date and 0 elsewhere, $D U_{t}\left(T_{b}\right)=1\left(t=T_{b}\right)$.

Table 6. Johansen co integration tests between budget balance $(s b)$ and current balance $(b c)$ with break variable in the constant

\begin{tabular}{lllll}
\hline $\begin{array}{l}\text { Number of cointegration } \\
\text { equations }\end{array}$ & \multicolumn{1}{l}{ Null } & Statistics & Critical value 5\% & Probability* \\
\hline H1(r) Maximum likelihood of & & & & \\
\cline { 2 - 5 } success & $r=0$ & 26,730 & 24,252 & 0,023 \\
\cline { 2 - 5 } & $r \leq 1$ & 10,019 & 17,147 & 0,395 \\
\hline H1(r) Trace & $r \leq 2$ & 4,284 & 3,841 & 0,038 \\
\cline { 2 - 5 } & $r=0$ & 41,033 & 35,010 & 0,010 \\
\cline { 2 - 5 } & $r \leq 1$ & 14,303 & 18,397 & 0,170 \\
\hline
\end{tabular}

Note: the optimal lag of this test is chosen according to the criteria of AIC and SC, * indicates a probability at the 5\% threshold. Source: Author based on BCEAO data.

The long-term analysis by the co integration technique also confirms the importance of the effects of these structural changes since the null hypothesis of no co integration is rejected at 5\% threshold. For trace and maximum likelihood tests, the existence of a co integration relationship is confirmed. This allows us to carry out both short and long-term analysis (see Table 7 below). 
Table 7. Johansen cointegration tests between budget balance ( $s b$ ) and current balance ( $b c$ ) with break dummy variable.

\begin{tabular}{ccccc}
\hline $\begin{array}{c}\text { Number of } \\
\text { cointegration equations }\end{array}$ & Null & Statistics & Critical value 5\% & Probability* \\
\hline \multirow{2}{*}{$H_{1}(r)$ Maximum } & $r=0$ & 30,198 & 0,007 \\
\cline { 2 - 4 } likelihood & $r \leq 1$ & 13,666 & 24,252 & 0,149 \\
\hline \multirow{2}{*}{$H_{1}(r)$ Trace } & $r \leq 2$ & 5,035 & 17,147 & 0,024 \\
\cline { 2 - 4 } & $r \leq 1$ & 48,900 & 3,841 & 0,000 \\
\cline { 2 - 4 } & $r \leq 2$ & 18,702 & 35,010 & 0,045 \\
\hline
\end{tabular}

Note: the optimal delay of this test is chosen according to the criteria of AIC and SC, * indicates a probability at the $5 \%$ threshold

Source: Author based on BCEAO data.

The normalized co integration coefficients indicate a significant reminder force towards equilibrium for an adjustment rate of $10.80 \%$ from current balance to the budget balance for the model indicating a breakthrough variable in the constant. Moreover, the model indicating a break dummy variable has a relatively lower adjustment rate of $8.31 \%$. These long-term equations are presented in appendix (see Table 9).

\subsection{Estimation of Non-Linear STAR Models}

Non-linearity tests indicate that linear model is rejected at the 5\% level and Terasvirta's (1994) F-statistics of sequential tests recommends logistic model (LSTAR) while Escribano-Jorda's (1999) F- statistics recommends the exponential model (ESTAR). $H_{0,1}$ is accepted and $H_{0,2}$ is rejected, so,we choose to present the estimation results of ESTAR models in the following table.

Table 8. Estimation results of non-linear ESTAR models

\begin{tabular}{ccc}
\hline Dependent variable with threshold & $b c(-3)$ & $s b(-3)$ \\
\hline$\beta_{1,0}$ & $-1,260^{*}(0,716)$ & $0,273^{* * *}(0,054)$ \\
\hline$\vartheta_{1,1}$ & $-0,340(1,562)$ & $0,0132(0,124)$ \\
\hline$\vartheta_{1,2}$ & $-1,217(1,263)$ & $-0,042^{* *}(0,013)$ \\
\hline$a_{1,0}$ & & $-0,297(0,213)$ \\
\hline$\vartheta_{2,1}$ & $-0,260^{* * *}(0,068)$ & $0,098(0,180)$ \\
\hline$\vartheta_{2,2}$ & $-0,010(2,848)$ & $0,037(0,077)$ \\
\hline$\vartheta_{2,3}$ & $\vartheta_{1,1}$ & $1573,076^{*}(1052,334)$ \\
\hline$\gamma$ & $\vartheta_{1,2}$ & $-0,024^{* * *}(0,002)$ \\
\hline$c$ & $18,592^{*}(0,158)$ & 0,305 \\
\hline$R^{2}$ & $0,131^{*}(0,059)$ & 1,079 \\
\hline$D W$ & 0,738 & 7,381 \\
\hline$J B$ & 0,685 & $7,140^{* *}$
\end{tabular}

Source: Author based on BCEAO data. Note: ***significant at $1 \%$, **significant at $5 \%$, significant at $10 \%$ and standard deviations in brackets.

Source: author table based on BCEAO data 
The results of the estimates of ESTAR models with two regimes are presented in Table 8 above. To illustrate the dynamics, the second column presents the estimated parameters of non-linear model following the effect of the budget balance variable on the current account. The third column presents the estimated parameters of a current account shock on the budget deficit. With regard to the significant number of coefficients, the results confirm a linear effect of double deficits from the current account to the budget balance. Similarly, in non-linear part of the equation, the disruption effect is greater when the current account deficit causes the budget deficit. The relatively higher value of $\gamma$ for effect on $s b$ suggest a faster regime change at $10 \%$ unlike the effect on the variable $b c$ which assumes a slow transition from one regime to another. The threshold value $c$ between revolutions is $-2.4 \%$ when $b c$ cause $s b$ at the $1 \%$ level. This value is even higher and positive (13.1\%) when $s b$ causes $b c$ but at the $10 \%$ level. On the other hand, in the non-linear part of the model, the coefficients are not significant for an optimal lag of our ESTAR results validate the assumption of twin deficits in Côte d' Ivoire which remains relatively high from the current balance to the budget balance. These results confirm the reasons for the deterioration of the budget deficit in relation to a certain structural weakness, an economy dependent on fluctuations in commodity prices, which is responsible for the trade deficit. In addition, the effects of current account instability on the fiscal balance are more rapid because economic agents anticipate relatively less deterioration in the current account balance than deterioration in fiscal balance. Hence, economic policies aimed at influencing the effect of the current balance would be more credible than those aimed at the effect of the budget balance. In other words, the Ivorian economy adopts a Keynesian performance in the presence in the event of trade policy or current account shocks and a performance that tends to be more or less Ricardian in presence of fiscal policy shock.

\section{Conclusion}

This article tests the hypothesis of double deficit in Côte d'Ivoire in non-linear framework. The Dicker-Fuller method, augmented with structural failure allows us to detect mainly a structural failure in 1990, a year marked by socio-economic events. As for the co integration method (Johansen, 1988; Johansen and Juselius, 1990), we adopt it by incorporating a dummy variable in 1990. This method reveals a long-term effect of current balance on the budgetary balance. In addition, economic agents faced with fiscal policies and trade balance shocks may revise their consumption and investment plans. But since their reaction and regime change are more likely to occur gradually than instantaneously, then we use autoregressive smooth transition models such as STAR. The estimation results of the STAR models also validate the assumption of double deficit in Côte d'Ivoire in the direction of current balance towards the budget balance. And the rather rapid effects of the instability of current balance on the budget balance show the lack of anticipation by economic agents of deterioration in the current balance compared to go down in the budget balance. As result, economic policies aimed at influencing the effect of the current balance would be more effective than those aimed at the effect of the budgetary balance. This suggests that the Ivorian economy adopts a Keynesian performance in the event of trade policy or current account shocks and a performance that tends to be more or less Ricardian in presence of fiscal policy shock.

\section{Acknowledgments}

I would like to thank the Peleforo University of Korhogo (Côte d'Ivoire) and the Laboratory for Economic Policy Analysis and Modelling (LAMPE).

\section{Data availability statement}

The data used in this study are freely available and can be consulted on Bank of West African States data bank.

\section{References}

Abell, J. (1990). Twin deficits during the 1980s. An empirical investigation. Journal of Macroeconomics, 12(1), 81-96. https://doi.org/10.1016/0164-0704(90)90057-H

Alexander, S. S. (1952 ). Effects of a Devaluation on a Trade Balance. International Monetary Fund Staff. Working Papers, 2, 263-78. https://doi.org/10.2307/3866218

Andrews, D., \& Ploberger, W. (1994). Optimal Tests When a Nuisance Parameter is Present Only under the Alternative. Econometrica, 1383-414. https://doi.org/10.2307/2951753

Antonio, A., \& Christophe, R. (2008). Budgetary and External Imbalances Relationship: a Panel Data Diagnostic, No 2008/45, Working Papers Department of Economics. ISEG - Lisbon School of Economics and Management.

Baharumshah, A. al. (2006). Testing Twin Deficits Hypothesis for ASEAN-4: Using VARs and Variance Decomposition. Journal of Asia Pacific Economy, 11(3), 331-354. https://doi.org/10.1080/13547860600764245

Barro, J. (1989). The Ricardian Approach to Budget Deficits, journal of economic perspectives. spring , pp. 37-54. https://doi.org/10.1257/jep.3.2.37 
Daly, V., \& Siddiki, J. (2009). The twin deficits in OECD countries: Cointegration analysis with regime shifts. Applied Economics Letters, 16(11), 1155-1164. https://doi.org/10.1080/13504850701349179

Darrat, A. (1988). Have Large Budget Deficits Caused Rising Trade Deficit? Southern Economic Journal., $54,879-87$. https://doi.org/10.2307/1059523

Dibooglu, S. (1997). Accounting for US current account deficits: an empirical investigation. Applied Economics, 29(6), 787-793. https://doi.org/10.1080/000368497326705

Dickey, D., \& Fuller, W. (1981). Likelihood ratio statistics for autoregressive time series with unit root. Econometrica, 49(4), 1057-1072. https://doi.org/10.2307/1912517

Enders, W., \& Siklos, P. (2001). Cointegration and Threshold Adjustment. Journal of Business and Statistics, 19, 166-176. https://doi.org/10.1198/073500101316970395

Escribano, A., \& Jorda, O. (1999). Improved Testing and Specification of Smooth Transition Regression Models. Time Series Analysis of Economic and Financial Data,, Kluwer Academic Publishers, Dordrecht. https://doi.org/10.1007/978-1-4615-5129-4_14

Fleming, J. (1962). Domestic Financial Policies Under Fixed and Under Floating Exchange Rates. Staff Papers, International Monetary Fund, 9(November), 369-379. https://doi.org/10.2307/3866091

Granger, C., \& Newbold, P. (1986). Forecasting Economic Time Series. Academic Presshttp, econpapers.repec.org/bookchap/eeemonogr/9780122951831.htm.

Grier, K., \& Haichun, Y. (2009). Twin Sons of Different Mothers. The Long and Short of Twin Deficits Debate. Economic Inquiry, 47(4), 625-638. https://doi.org/10.1111/j.1465-7295.2008.00162.x

Hodrick, R., \& Prescott. (1997). Post-War Business Cycles: An Empirical Investigation. Journal of Money, Credit and Banking, 29(1), 1-16. https://doi.org/10.2307/2953682

Holmes, M. (2006). How sustainable are OECD current account balances in the long run? Manchester School, 74, 626-643. https://doi.org/10.1111/j.1467-9957.2006.00514.x

Johansen, S. (1988). Statistical analysis of cointegration vectors. Journal of Economic Dynamics and Control, 12(2-3), 231-254. https://doi.org/10.1016/0165-1889(88)90041-3

Johansen, S., \& Juselius, K. (1989). Maximum Likelihood Estimation and Inference on Cointegration-with applications to the demand for money. Oxfort Bulletin of Economics and Statistics, 52(2), 169-210. https://doi.org/10.1111/j.1468-0084.1990.mp52002003.x

Kalou, S., \& Paleologou, S. M. (2012). The twin deficits hypothesis: Revisiting an EMU country. Journal of Policy Modeling, 34(2), 230-241. https://doi.org/10.1016/j.jpolmod.2011.06.002

Kaufmann, S. A. (2002). The Austrian current account deficit: Driven by twin deficits or by intertemporal expenditure allocation? Empirical Economics, 27(3), 529-542. https://doi.org/10.1007/s001810100094

Khalid, A., \& Guan, T. (1999). Causality tests of budget and current account deficits: Cross-country comparisons. Empirical Economics, 24(3), 389-402. https://doi.org/10.1007/s001810050062

Kim, S., \& Kouassi, E. (2004). Causality tests of the relationship between the twin deficits. Empirical Economics, 29(3), 503-525. https://doi.org/10.1007/s00181-003-0181-5

Kim, S., \& Roubini, N. (2008). Twin deficit or twin divergence? Fiscal policy, current account, and real exchange rate in the U.S. Journal of International Economics, 74(2), 362-383. https://doi.org/10.1016/j.jinteco.2007.05.012

Luukkonen, R., Pentti, S., \& Timo, T. (1988). Testing Linearity Against Smooth Transition Autoregressive Models. Biometrika, 75, 491-499. https://doi.org/10.1093/biomet/75.3.491

Marinheiro, C. (2008). Ricardian equivalence, twin deficits, and the Feldstein-Horioka puzzle in Egypt. Journal of Policy Modeling, 30(6), 1041-1056. https://doi.org/10.1016/j.jpolmod.2007.12.001

Miller, S., \& Russek, F. (1989). Are The Twin Deficits Really Related? Contemporary Economic Policy, Western Economic Association International, 7(4), 91-115. https://doi.org/10.1111/j.1465-7287.1989.tb00577.x

Mohammadi, H. (2004). Budget deficits and the current account balance: new evidence from panel data. Journal of economics and finance, 28(1). https://doi.org/10.1007/BF02761453

Mundell, K. (1963). Capital Mobility and Stabilization Policy under Fixed and Flexible Exchange Rates. The Canadian Journal of Economics and Political Science, 29(4), 475-485. https://doi.org/10.2307/139336

Normandin, M. (1999). Budget deficit persistence and the twin deficits hypothesis. Journal of International Economics, 
49(1), 171-193. https://doi.org/10.1016/S0022-1996(98)00058-0

Perron, P. (1989). The Great Crash, the Oil Price Shock, and the Unit Root Hypothesis. Econometrica, 57(6), 1361-1401. https://doi.org/10.2307/1913712

Perron, P., \& Vogelsang, T. (1992a). Nonstationary and level shifts with an application to Purchasing Power Parity. Journal of Business and Economic Statistics, 10, 301-320. https://doi.org/10.1080/07350015.1992.10509907

Perron, P., \& Vogelsang, T. (1992b). Testing for a unit root in time series with a changing mean: Correction and extensions. Journal of Business and Economic Statistics, 10, 311-340. https://doi.org/10.2307/1391823

Phillips, P. (1988). Trends and Random Walks in Macroeconomic Time Series: Further Evidence From a New Approach. Journal of Economics Dynamics and Control, 12, 297-332. https://doi.org/10.1016/0165-1889(88)90043-7

Piersanti, G. (2000). Current account dynamics and expected future budget deficits: some international evidence. Journal of International Money and Finance, 19(2), 255-271. https://doi.org/10.1016/S0261-5606(00)00004-8

Quandt, R. (1960). Tests of the Hypothesis that a Linear Regression System Obeys Two Separate Regimes. Journal of the American Statistical Association, 55(290), 324-30. https://doi.org/10.1080/01621459.1960.10482067

Robert, J., \& Prescott, E. (1997). Postwar U.S. Business Cycles: An Empirical Investigation. Source: Journal of Money, Credit and Banking, 29(1), 1-16. https://doi.org/10.2307/2953682

Rosenswieg, J., \& Ellis, T. (1993). Fiscal Policy and Trade Adjustment: Are the Deficits Really Twins? Economic Inquiry, 31(4), 580-94. https://doi.org/10.1111/j.1465-7295.1993.tb00892.x

Summers, L. (1988). Tax Policy and International Competitiveness. Frankel, J. (Ed.) : International Aspects of Fiscal Policies (NBER conference report), Chicago : Chicago University Press, 349-375.

Teräsvirta, \& Timo. (1994). Specification, Estimation, and Evaluation of Smooth Transition Autoregressive Models. Journal of the American Statistical Association, 89, 208-218. https://doi.org/10.1080/01621459.1994.10476462

Teräsvirta, C. F. (1994). Testing the constancy of regression parameters against continuous structural change. Journal of Econometrics, 62(2), 211-228. https://doi.org/10.1016/0304-4076(94)90022-1

Terasvirta, T. (1994). Specification, estimation, and evaluation of smooth transition autoregressive models. Journal of American Statatistic Association, 89(425), 208-218. https://doi.org/10.1080/01621459.1994.10476462.

Teräsvirta, T. (2005). Linear models, smooth transition autoregressions, and neural networks for forecasting macroeconomic time series: a re-examination. Int J Forecast, 21, 755-774. https://doi.org/10.1016/j.ijforecast.2005.04.010

Vogelsang, T., \& Perron, P. (1998). Additional tests for a unit root allowing for a break in the trend function at an unknown time. International Economic Review, 39, 1073-1100. https://doi.org/10.2307/2527353

Zivot, E., \& Andrews, D. (1992). Further Evidence of the Great Crash, The Oil Price Shock and the Unit Root Hypothesis. Journal of Business and Economic Statistics, 10(3), 251-270. https://doi.org/10.1080/07350015.1992.10509904

Zubaidi, A. (2006). Testing Twin Deficits Hypothesis using VARs and Variance Decomposition. Journal of the Asia Pacific Economy, 11(3), 331-354. https://doi.org/10.1080/13547860600764245 


\section{Appendix}

Table 9. Sequential Terasvirta tests (1994)

\begin{tabular}{lll}
\hline Nul hypothesis & F-statistic & Probability \\
\hline H3: $\quad$ b3 $=0$ & 0,744 & 0,569 \\
H2: $\quad$ b2 $=0 \mid b 3=0$ & 0,362 & 0,833 \\
H1: $\quad$ b1 $=0 \mid b 2=b 3=0$ & 8,767 & 0,000 \\
\hline
\end{tabular}

Recommended model: first-rate logistics. $\operatorname{Pr}(\mathrm{H} 3)<=\operatorname{Pr}(\mathrm{H} 2) \quad$ ou $\operatorname{Pr}(\mathrm{H} 1)<=\operatorname{Pr}(\mathrm{H} 2)$

Source: author table based on BCEAO’ data

Table 10. Escribano-Jorda tests (1999)

\begin{tabular}{lll}
\hline Nul hypothesis & F-statistics & Probability \\
\hline HOL: $\quad$ b2=b4=0 & 1,055 & 0,425 \\
H0E: $\quad$ b1=b3=0 & 0,962 & 0,486 \\
\hline
\end{tabular}

Recommended model: exponential with a non-zero threshold.

$\operatorname{Pr}(\mathrm{HOL})<\operatorname{Pr}(\mathrm{HOE})$ with $\operatorname{Pr}(\mathrm{H} 0 \mathrm{~L})>=0.05$.

Source: author's table based on BCEAO data

Table 11. Pairwise Granger Causality Tests

\begin{tabular}{llll}
\hline & Nul hypothesis & F-statistics & Probability \\
\hline Sample 1965-2017 & SB does not Granger Cause BC & 2.4092 & 0.1011 \\
& BC does not Granger Cause SB & 3.6846 & 0.0328 \\
\hline Sample 1965-1990 & SB does not Granger Cause BC & 8.2291 & 0.0027 \\
& BC does not Granger Cause SB & 0.6646 & 0.5260 \\
\hline Sample 1991-2017 & SB does not Granger Cause BC & 0.0578 & 0.9440 \\
& BC does not Granger Cause SB & 6.5605 & 0.0064 \\
\hline
\end{tabular}

Note: optimal lag 2
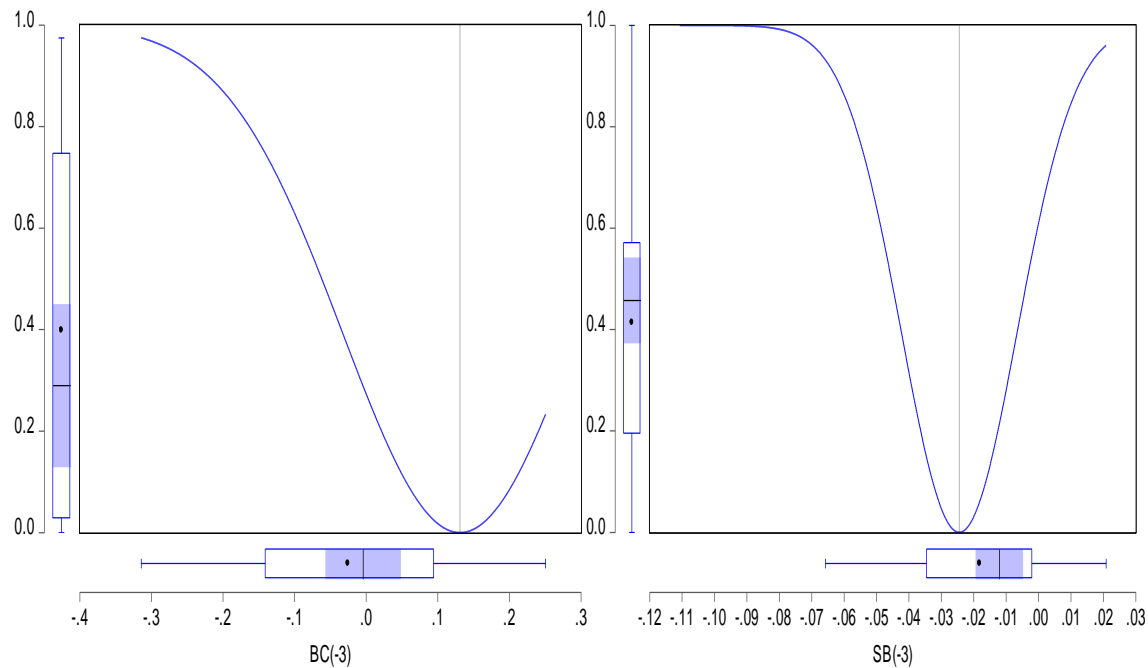

Figure 3. Representations of functions (ESTAR) at the respective thresholds of $c=0.131$ and $c=-0.024$

Source: author figure based on BCEAO' data

\section{Copyrights}

Copyright for this article is retained by the author(s), with first publication rights granted to the journal.

This is an open-access article distributed under the terms and conditions of the Creative Commons Attribution license which permits unrestricted use, distribution, and reproduction in any medium, provided the original work is properly cited. 